\title{
Ripening Proficiencies of Polaris, CP 70139, RH 1622, Ripenthol, and PP 757 in Early-Adult Sugarcane ${ }^{1}$
}

\author{
Alex G. Alexander ${ }^{2}$
}

\begin{abstract}
Three candidate chemical ripeners showing exceptional activity in screening tests with plantlets were reevaluated in young-adult cane, 14 weeks of age, having fully-developed canopies and millable stems. Polaris, and CP 70139 (Monsanto Agricultural Products Co.) and PP 757 (ICI United States, Inc.) were readministered to the same variety identically propagated by sand culture. Two previously inactive materials, RH 1622 (Rohm and Haas Co.) and Ripenthol (Pennwalt Corp.), were also reexamined. Treatment interval was extended from 21 to 42 days. Polaris, CP 70139, and PP 757 again excelled in their effects on growth, tissue sugar and protein components, and enzyme behavior, while RH 1622 and Ripenthol produced little response. Juice quality was significantly improved by the three compounds. Early-adult responses closely conformed to those obtained with plantlets. Results are discussed in terms of an increased validity for ripener screening with plantlets. The young-adult cane is further discussed as a model for efficiency studies on successful candidate materials.
\end{abstract}

\section{INTRODUCTION}

Recent evidence suggests that sugarcane plantlets propagated by sand culture offer accurate and inexpensive models for the rapid screening of chemical ripeners (3). The method is heavily reliant upon rudimentary stem tissues for measurement of growth, sugar, and enzymic parameters which also characterize adult plants. A verification of plantlet data through the qualitative improvement of mature stalks, similarly propagated with controlled water and nutrient regimes, would both strengthen the plantlet-screening concept and establish an adult model for usageefficiency studies on successful candidate materials.

From plantlet screening experiments in Puerto Rico (3), two compounds have emerged showing exceptional ability to repress growth and acid invertase, and to produce sucrose accumulations in plants otherwise

${ }^{1}$ Manuscript submitted to the Editorial Board November 4. 1975.

${ }^{2}$ Plant Physiologist, Agricultural Experiment Station, Mayagüez Campus, University of Puerto Rico, Río Piedras, P.R. 
geared for intensive sucrose utilization. These are Monsanto's CP $70139,{ }^{3}$ and the compound PP 757 produced by ICI United States, Inc. In the present study these materials were reevaluated on early-adult plants also propagated by sand culture. Millable stalks were included to measure chemical effects on juice quality, and the time-course for chemical action was extended to 6 weeks in conformation with present thinking on field cane requirements (4).

\section{MATERIALS AND METHODS}

One-eye cuttings of the interspecific hybrid PR $980^{4}$ were propagated in quartz sand using controlled water and nutrient regimes as previously described (1). At 14 weeks of age, test compounds were administered as aqueous foliar sprays containing $3000 \mathrm{p} / \mathrm{m}$ active ingredient plus $0.10 \%$ Tween 20 as wetting agent. Application time was $0730 \mathrm{~h}$. In addition to CP 70139 and PP 757, the compounds RH 1622 (Rohm and Haas Co.) and Ripenthol (Pennwalt Corp., Agchem-Decco Division) were also tested in spite of negative results obtained earlier with plantlets. Control plants received Tween 20 in distilled water. Polaris, a commerical plant growth regulator marketed by the Monsanto Agricultural Products Co., was employed as a second control or standard chemical ripener. All solutions were administered until runoff. There were three replications in an incomplete randomized block design.

Samples consisting of six uniform plants per replicate were harvested at "0 days", i.e., just prior to chemical applications, and at the same hour 42 days thereafter. Green weight measurements were taken for whole plants, tops, and millable stems, the latter consisting of 10 to 12 joints by the second harvest. Approximate leaf and immature storage tissues were frozen for sugar, enzyme, and soluble protein analyses as described in a prior publication (1). All replicated data were submitted to statistical analysis in accordance with the Duncan New Multiple Range Test.

\section{RESULTS}

In earlier tests with plantlets, the compounds Polaris, CP 70139, and PP 757 had each excelled at the common rate of $3000 \mathrm{p} / \mathrm{m}$ over a time-course of 21 days (3). During the present work with young-adult cane, over a time-course of 42 days, these materials again excelled in their effects on growth (table 1), juice quality (table 2), tissue sugar and protein components (table 3), and enzymic behavior (table 4).

${ }^{3}$ Trade names are used in this publication solely for the purpose of providing specific information. Mention of a trade name does not constitute a guarantee or warranty of equipment or materials by the Agricultural Experiment Station of the University of Puerto Rico or an endorsement over other equipment or materials not mentioned.

${ }^{4} 11 / 16$ S. officinarum, 3/16 S. spontaneum, 2/16 S. sinense. 
TABLE 1.-Growth responses of early-adult sugarcane treated with candidate chemical ripeners ${ }^{1}$

\begin{tabular}{|c|c|c|c|c|c|c|c|c|c|}
\hline \multirow{3}{*}{$\begin{array}{l}\text { Candidate } \\
\text { material }^{1}\end{array}$} & \multicolumn{9}{|c|}{ Green weight values ( $\mathrm{g} / \mathrm{plant}$ ), at 0 and 42 days, for- } \\
\hline & \multicolumn{3}{|c|}{ Total green weight } & \multicolumn{3}{|c|}{ Top weight } & \multicolumn{3}{|c|}{ Stem weight } \\
\hline & 0 & 42 & $\%$ change & 0 & 42 & $\%$ change & 0 & 42 & \% change \\
\hline Control & $220 a^{2}$ & 528 a & $140.0 \mathrm{a}$ & $156 a$ & $293 \mathrm{a}$ & $87.8 \mathrm{a}$ & $65 \mathrm{a}$ & $234 \mathrm{a}$ & $260.0 \mathrm{a}$ \\
\hline Polaris & $225 \mathrm{a}$ & $241 \mathrm{c}$ & $7.1 \mathrm{~cd}$ & $154 \mathrm{a}$ & $120 \mathrm{c}$ & $-22.1 \mathrm{~cd}$ & $71 \mathrm{a}$ & $122 \mathrm{c}$ & $71.8 \mathrm{de}$ \\
\hline CP 70139 & $229 \mathrm{a}$ & $134 \mathrm{~d}$ & $-41.5 \mathrm{~d}$ & $160 \mathrm{a}$ & $53 \mathrm{~d}$ & $-66.9 \mathrm{a}$ & $70 a$ & $82 \mathrm{~d}$ & $17.1 \mathrm{e}$ \\
\hline RH 1622 & $239 a$ & $468 \mathrm{a}$ & $95.8 \mathrm{ab}$ & $162 \mathrm{a}$ & $253 a$ & $56.2 \mathrm{ab}$ & $76 a$ & 215 a & $182.9 \mathrm{bc}$ \\
\hline Ripenthol & $236 a$ & $509 \mathrm{a}$ & $115.7 \mathrm{a}$ & $162 \mathrm{a}$ & $273 \mathrm{a}$ & $68.5 \mathrm{a}$ & $74 \mathrm{a}$ & 236 a & $218.9 \mathrm{ab}$ \\
\hline PP 757 & $226 \mathrm{a}$ & $331 \mathrm{~b}$ & $46.5 \mathrm{bc}$ & $161 \mathrm{a}$ & $181 \mathrm{~b}$ & $12.4 \mathrm{bc}$ & $65 \mathrm{a}$ & $151 \mathrm{~b}$ & $132.3 \mathrm{~cd}$ \\
\hline
\end{tabular}

${ }^{1}$ Each material was administered as an aqueous foliar spray containing $3000 \mathrm{p} / \mathrm{m}$ active ingredient plus $0.1 \%$ Tween 20 as wetting agent. PP 757 was first dissolved in methyl cellosolve and then dispersed in distilled water. Control plants received wetting agent in distilled water. Application time was 0730 h. The " 0 day" harvest was taken just prior to spray application and a second harvest was taken at the same hour 42 days thereafter.

${ }^{2}$ Mean values in the same column bearing unlike letters differ significantly $(\mathrm{P}<.05)$.

TABLE 2.-Brix and polarization values for early-adult sugarcane treated with candidate chemical ripeners

\begin{tabular}{|c|c|c|c|c|c|c|}
\hline \multirow{3}{*}{$\begin{array}{l}\text { Candidate } \\
\text { material }^{1}\end{array}$} & \multicolumn{6}{|c|}{ Mean values, at 0 and 42 days, for- } \\
\hline & \multicolumn{3}{|c|}{ Brix } & \multicolumn{3}{|c|}{ Polarization } \\
\hline & 0 & 42 & $\%$ change & 0 & 42 & $\%$ change \\
\hline Control & $7.2 \mathrm{a}^{2}$ & $8.3 \mathrm{c}$ & $15.3 \mathrm{de}$ & $12.4 \mathrm{a}$ & $15.1 \mathrm{c}$ & $21.8 \mathrm{~d}$ \\
\hline Polaris & $6.2 \mathrm{a}$ & $16.1 \mathrm{a}$ & $159.7 \mathrm{a}$ & $7.9 \mathrm{a}$ & $49.2 \mathrm{a}$ & $522.8 \mathrm{a}$ \\
\hline CP 70139 & $5.8 \mathrm{a}$ & $12.2 \mathrm{~b}$ & $110.3 \mathrm{~b}$ & $7.5 \mathrm{a}$ & $29.1 \mathrm{~b}$ & $288.0 \mathrm{~b}$ \\
\hline RH 1622 & $6.3 \mathrm{a}$ & $8.1 \mathrm{c}$ & $28.6 d$ & $8 . \overline{\mathrm{j}} \mathrm{a}$ & $15.4 \mathrm{c}$ & $81.2 \mathrm{~cd}$ \\
\hline Ripenthol & $7.5 \mathrm{a}$ & $7.1 \mathrm{c}$ & $-5.3 \mathrm{e}$ & $9.6 \mathrm{a}$ & $12.6 \mathrm{c}$ & $31.3 \mathrm{~d}$ \\
\hline PP 757 & $6.6 \mathrm{a}$ & $11.1 \mathrm{~b}$ & $68.2 \mathrm{c}$ & $9.3 \mathrm{a}$ & $30.0 \mathrm{~b}$ & $222.6 \mathrm{bc}$ \\
\hline
\end{tabular}

${ }^{2}$ Administered at $0730 \mathrm{~h}$ as aqueous foliar sprays containing $3000 \mathrm{p} / \mathrm{m}$ active ingredient plus $0.10 \%$ Tween 20 .

${ }^{2}$ Mean values in the same column bearing unlike letters differ significantly $(\mathrm{P}<.05)$.

Only one plantlet-parameter response failed to reemerge in adult cane, that of a severe trehalase repression by Polaris, CP 70139, and PP 757 (3). Polaris alone produced this effect in adult plants (table 4). This may be accountable to laboratory procedure owing to an inherent instability of trehalase and the attendant difficulty in preparing and measuring this enzyme in wholly viable form.

\section{DISCUSSION}

SIGNIFICANCE OF PLANTLET RESPONSES REPRODUCED IN YOUNG-ADULT CANE

It was previously stated that a ripener's effects on plantlets would probably, but not definitely, appear also in adult plants given identical 
TABLE 3.-Sugar and soluble protein components of early-adult sugarcane treated with candidate chemical ripeners

\begin{tabular}{|c|c|c|c|c|c|c|c|c|c|}
\hline \multirow{3}{*}{$\begin{array}{l}\text { Candidate } \\
\text { material }^{1}\end{array}$} & \multicolumn{9}{|c|}{$\mathrm{Mg} / \mathrm{g}$ dry wt, at 0 and 42 days, for- } \\
\hline & \multicolumn{3}{|c|}{ Sucrose } & \multicolumn{3}{|c|}{ Total reducing sugars } & \multicolumn{3}{|c|}{ Soluble protein } \\
\hline & 0 & 42 & $\%$ change & 0 & 42 & $\%$ change & 0 & 42 & $\%$ change \\
\hline \multicolumn{10}{|c|}{ Leaf tissue } \\
\hline Control & $37.9 a^{2}$ & $32.5 \mathrm{c}$ & $-14.3 \mathrm{c}$ & $19.4 \mathrm{a}$ & $26.5 \mathrm{~b}$ & $36.6 \mathrm{bc}$ & $6.5 \mathrm{~b}$ & $7.3 \mathrm{~d}$ & $12.3 \mathrm{~cd}$ \\
\hline Polaris & $38.0 \mathrm{a}$ & $161.0 \mathrm{a}$ & $323.7 \mathrm{a}$ & $20.4 \mathrm{a}$ & $28.3 \mathrm{~b}$ & $38.7 \mathrm{bc}$ & $8.2 \mathrm{a}$ & $14.2 \mathrm{~b}$ & $73.2 \mathrm{~b}$ \\
\hline CP 70139 & $41.4 \mathrm{a}$ & $169.8 \mathrm{a}$ & $310.1 \mathrm{a}$ & $20.3 \mathrm{a}$ & $58.4 \mathrm{a}$ & $187.7 \mathrm{a}$ & $8.4 \mathrm{a}$ & $19.6 \mathrm{a}$ & $133.3 \mathrm{a}$ \\
\hline RH 1622 & $40.4 \mathrm{a}$ & $42.0 \mathrm{c}$ & $4.0 \mathrm{c}$ & $20.0 a$ & $27.0 \mathrm{~b}$ & $35.0 \mathrm{bc}$ & $6.9 \mathrm{ab}$ & $6.7 \mathrm{de}$ & -2.9 de \\
\hline Ripenthol & $38.9 \mathrm{a}$ & $30.7 \mathrm{c}$ & $-20.8 \mathrm{c}$ & $19.2 \mathrm{a}$ & $17.9 \mathrm{c}$ & $-6.8 c$ & $6.5 \mathrm{~b}$ & $5.1 \mathrm{e}$ & $-21.5 \mathrm{e}$ \\
\hline PP 757 & $41.6 \mathrm{a}$ & $71.0 \mathrm{~b}$ & $70.7 \mathrm{~b}$ & $21.2 \mathrm{a}$ & $30.8 \mathrm{~b}$ & $45.3 \mathrm{~b}$ & $7.7 \mathrm{ab}$ & $9.9 \mathrm{c}$ & $29.6 \mathrm{c}$ \\
\hline \multicolumn{10}{|c|}{ Immature storage tissue } \\
\hline Control & $54.9 \mathrm{a}$ & $77.6 \mathrm{~d}$ & $41.4 \mathrm{~d}$ & $188.3 \mathrm{a}$ & $193.7 \mathrm{a}$ & $2.9 \mathrm{a}$ & $35.0 \mathrm{a}$ & $41.5 \mathrm{a}$ & $18.6 \mathrm{a}$ \\
\hline Polaris & $61.8 \mathrm{a}$ & $257.6 \mathrm{a}$ & $316.8 \mathrm{a}$ & $192.0 \mathrm{a}$ & $98.7 \mathrm{~b}$ & $-48.6 \mathrm{~b}$ & $34.8 \mathrm{a}$ & $14.3 \mathrm{~d}$ & $-58.9 \mathrm{e}$ \\
\hline CР 70139 & $61.4 \mathrm{a}$ & $206.2 \mathrm{~b}$ & $235.8 \mathrm{~b}$ & $183.7 \mathrm{a}$ & $109.9 \mathrm{~b}$ & $-40.2 \mathrm{~b}$ & $35.7 \mathrm{a}$ & $23.3 \mathrm{c}$ & $-34.7 \mathrm{~d}$ \\
\hline RH 1622 & $59.8 \mathrm{a}$ & $73.2 \mathrm{~d}$ & $22.4 \mathrm{~d}$ & $186.4 \mathrm{a}$ & $173.8 \mathrm{a}$ & $-6.8 \mathrm{a}$ & $30.2 \mathrm{a}$ & $37.8 \mathrm{ab}$ & $18.5 \mathrm{a}$ \\
\hline Ripenthol & $53.8 \mathrm{a}$ & $78.6 \mathrm{~d}$ & $46.1 \mathrm{~d}$ & $187.8 \mathrm{a}$ & $178.5 \mathrm{a}$ & $-5.0 \mathrm{a}$ & $34.2 \mathrm{a}$ & $35.2 \mathrm{~b}$ & $2.9 \mathrm{~b}$ \\
\hline PP 757 & $56.7 \mathrm{a}$ & $165.3 \mathrm{c}$ & $191.5 \mathrm{c}$ & $189.0 \mathrm{a}$ & $173.8 \mathrm{a}$ & $-8.1 \mathrm{a}$ & $28.2 \mathrm{a}$ & $24.5 \mathrm{c}$ & $-13.2 \mathrm{c}$ \\
\hline
\end{tabular}

${ }^{1}$ Administered at $0730 \mathrm{~h}$ as aqueous foliar sprays containing $3000 \mathrm{p} / \mathrm{m}$ active ingredient plus $0.10 \%$ Tween 20 .

${ }^{2}$ Mean values in the same column bearing unlike letters differ significantly $(\mathrm{P}<.05)$. 
treatments (3). This qualification had stemmed from the lack of anatomical development in a juvenile source-to-sink system otherwise complete from a biochemical point of view. Indeed, the transformations that occur in this system between the early-juvenile and young-adult stages vastly exceed the changes that can occur thereafter until final senescence. Hence, the reemergence of growth and tissue-component responses to Polaris, CP 70139, and PP 757, sustained at this time by juice quality improvement by each material, appreciably strengthens the earlier conclusion. Alternately, there appears to be little justification for continued testing of materials giving negative results at both the plantlet and early-adult stages.

TABLE 4.-Enzymic responses in early-adult sugarcane treated with candidate chemical ripeners

\begin{tabular}{|c|c|c|c|c|c|c|}
\hline \multirow{2}{*}{$\begin{array}{l}\text { Candidate } \\
\text { material }\end{array}$} & \multicolumn{6}{|c|}{$\mathrm{Mg}$ product/g tissue/h, at 0 and 42 days, for- } \\
\hline & 0 & 42 & $\%$ change & 0 & 42 & $\%$ change \\
\hline & \multicolumn{3}{|c|}{ Acid invertase } & \multicolumn{3}{|c|}{ ATP-ase } \\
\hline Control & $26.7 \mathrm{a}^{2}$ & $19.1 \mathrm{a}$ & $-28.5 \mathrm{a}$ & $16.0 \mathrm{a}$ & 14.7 a & $-8.1 \mathrm{a}$ \\
\hline Polaris & $24.1 \mathrm{a}$ & $1.2 \mathrm{~b}$ & $-95.0 \mathrm{c}$ & $17.3 \mathrm{a}$ & $8.2 b$ & $52.6 \mathrm{c}$ \\
\hline CP 70139 & $25.4 \mathrm{a}$ & $5.7 \mathrm{~b}$ & $-77.6 \mathrm{~b}$ & $16.6 \mathrm{a}$ & $9.6 \mathrm{~b}$ & $-42.2 \mathrm{c}$ \\
\hline RH 1622 & $26.6 \mathrm{a}$ & $18.9 \mathrm{a}$ & $-28.9 \mathrm{a}$ & $15.5 \mathrm{a}$ & $13.2 \mathrm{a}$ & $-14.8 \mathrm{ab}$ \\
\hline Ripenthol & $27.5 \mathrm{a}$ & $17.4 \mathrm{a}$ & $-36.7 \mathrm{a}$ & $17.5 \mathrm{a}$ & $14.3 \mathrm{a}$ & $-18.3 \mathrm{ab}$ \\
\hline \multirow[t]{2}{*}{ PP 757} & $22.0 \mathrm{a}$ & $7.5 \mathrm{~b}$ & $-65.9 \mathrm{~b}$ & $17.0 \mathrm{a}$ & $10.5 b$ & $-26.5 b$ \\
\hline & \multicolumn{3}{|c|}{ Beta-amylase } & \multicolumn{3}{|c|}{ Trehalase } \\
\hline Control & $694 \mathrm{c}$ & $757 \mathrm{a}$ & $9.1 \mathrm{a}$ & $2.85 \mathrm{a}$ & $1.27 \mathrm{a}$ & $-55.4 \mathrm{a}$ \\
\hline Polaris & $816 a b$ & $465 \mathrm{c}$ & $-43.0 c$ & $2.90 \mathrm{a}$ & $.22 \mathrm{~b}$ & $-92.4 b$ \\
\hline CP 70139 & $866 a$ & $413 c$ & $-52.3 c$ & $2.71 \mathrm{a}$ & $1.40 \mathrm{a}$ & $-48.3 \mathrm{a}$ \\
\hline RH 1622 & $771 \mathrm{bc}$ & $750 \mathrm{a}$ & $-2.7 \mathrm{a}$ & $2.78 \mathrm{a}$ & $1.29 \mathrm{a}$ & $-53.6 \mathrm{a}$ \\
\hline Ripenthol & $838 a b$ & $778 \mathrm{a}$ & $-7.2 \mathrm{a}$ & $2.84 \mathrm{a}$ & $1.44 \mathrm{a}$ & $-49.3 \mathrm{a}$ \\
\hline PP 757 & $824 a b$ & $613 b$ & $-25.6 \mathrm{~b}$ & $2.87 \mathrm{a}$ & $1.22 \mathrm{a}$ & $-57.5 \mathrm{a}$ \\
\hline
\end{tabular}

${ }^{1}$ Administered at $0730 \mathrm{~h}$ as aqueous foliar sprays containing $3000 \mathrm{p} / \mathrm{m}$ active ingredient plus $0.10 \%$ Tween 20 .

${ }^{2}$ Mean values in the same column bearing unlike letters differ significantly $(\mathrm{P}<.05)$.

\section{CHEMICAL ACTION RELATIVE TO THE AGING PLANT AND}

TIME-COURSE EXTENSION

The changes produced in adult plants by each compound show a striking conformity to their action in plantlets. CP 70139 had shown superior activity in plantlets relative to the standard control and Polaris, while PP 757 was slightly less active than Polaris (3). The three ripeners were again active in adult plants (tables 1-4), the main difference being a superiority of Polaris over CP 70139 in its influence on juice quality (table 2) and tissue-component levels (tables 3 and 4). This reversion should not be interpreted in terms of absolute activity potentials but 
rather as an artifact of the time-course extension from 21 to 42 days. In both plantlets and young-adult cane, Polaris at $3000 \mathrm{p} / \mathrm{m}$ produces a growth suspension without otherwise severely damaging the plant. On the other hand, the action of CP 70139 is terminal at this level and this is indicated by its negative growth values recorded in table 1 . The younger internodes begin to shrivel by 42 days and there is evidence of biodeterioration. Leaf and meristem samples bear a progressively higher proportion of dead tissues with increasing time. The latter produce a dilution effect on sucrose and enzyme values. Taken together, the evidence portrays an excessively powerful action by CP 70139, and the prior conclusion that this compound should be used, if used at all, in smaller quantities than Polaris (3) is sustained for adult cane.

Some effects of advancing plant age and the attendant increase of tissue mass on ripener performance are graphically illustrated in figure 1. Percent change for the 21- and 42-day time-courses are shown for three decisive parameters, i.e., total green weight, acid invertase, and sucrose content of immature storage tissue. Green weight changes present almost identical patterns for plantlets and adult cane. However, the lower magnitude of change shown by the adult control reflects an increased plant bulk which is progressively more difficult to alter; a fully mature plant might indicate virtually no response at all to a growth repressant. Acid invertase gradually disappears from an aging plant, and this trend is already established by the adult control depicted in figure 1. Nonetheless, the ripeners Polaris, CP 70139, and PP 757 retain a statistically significant repression at this stage relative to the control. The same compounds produced large to moderate sucrose increases in the immature storage tissues of adult plants (fig. 1). This is not merely a reflection of the full canopy which now sends a continual flow of sucrose to expanding storage tissues; on the contrary, the adult control contains less sucrose than the plantlet control. A probable explanation lies in the opportunity now afforded these ripeners to improve the operation of an extended transport and storage system which was not extant in plantlets.

\section{EARLY-ADULT CANE AS A MODEL FOR RIPENER EFFICIENCY RESEARCH}

The almost identical reproduction of plantlet responses to candidate ripeners in adult cane strengthens the validity of plantlet usage for chemical screening. However, there are added implications for the use of early-adult plants in ripener efficiency studies on successful candidate materials. A great deal of work is needed with even the most successful compound that emerges from screening trials owing to the divergent conditions which characterize regional sugar industries.

There are numerous factors, both cultural and physiological, for which an inadequate consideration has confounded cane ripener research for 

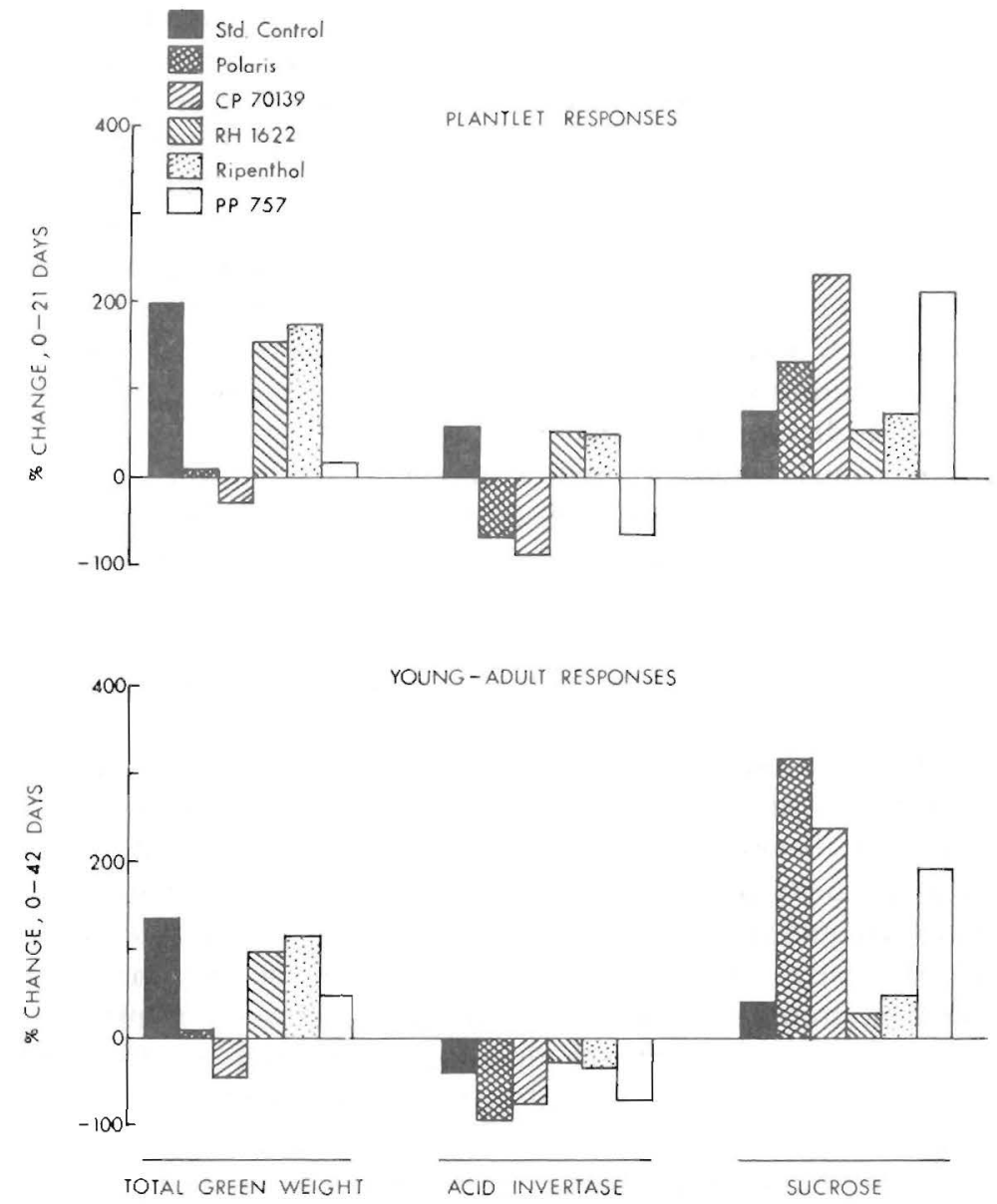

FIG. 1.-Responses of plantlets and young-adult sugarcane to identical treatments with five candidate chemical ripeners. The activity time-course was 21 days for plantlets and 42 days for early-adult cane. Acid invertase and sucrose values are for immature storage tissue. All values shown for Polaris, CP 70139, and PP 757 deviate significantly from the standard control $(\mathrm{P}<.05)$.

more than three decades (2, pp. 442-67). For example, in addition to a generally recognized varietal factor, there are questions as to the period in the crop cycle when chemical treatments will be most effective. Should they be given early when growth is still intense, or later to prevent a reversion to growth by naturally-ripened plants? Is it possible to extend the growth period with water and nitrogen, and then largely replace natural ripening by chemical means? Can chemical ripeners produce added quality in situations where good natural ripening has never been a problem? Should ripeners be used similarly under both 
humid and dry cultural conditions? With regard to cane breeding, can ripeners produce an acceptable quality in high-tonnage, low-quality progeny which are otherwise discarded from a breeding program? From a physiological standpoint, when is the correct time of day to administer a given material, and what is the correct number and frequency of applications needed for optimal effect? How much time is needed for a compound to act, and for how long will its action persist? Questions relating to the correct regimes for illumination, day and night temperatures, nitrogen, and moisture will need to be answered, as will others relating to coadministration with a second compound, and of wetting agents and additives to enhance a material's effect.

Quite obviously, even a single confirmed ripener will need a major expenditure of time and resources to define its regional requirements for optimal action. This research should not be done piecemeal, but rather in accordance with a preconceived and systematic plan, based on a suitable model in which major regional factors can be simulated. For this purpose the early-adult cane, as for example the hybrid PR 980 herein examined between 14 and 20 weeks of age, emerges as a very useful tool. It is a true adult having a full canopy of 8 to 10 viable leaf ranks. It, will flower profusely at this stage in the field and to a lesser degree in the greenhouse. It bears a millable stem composed of 8 to 12 joints in an authentic maturity profile. At 14 to 20 weeks its source-to-sink system is biochemically and anatomically complete, but it is still small enough to be moved easily within a greenhouse or to be accommodated in controlled-environment chambers. Discrete regimes for humid or dry culture, rapid growth, natural ripening, and reversion to growth by ripened plants are readily simulated by control of its nitrogen and moisture supplies.

Perhaps more important still, the young adult cultured in sand offers an answer to the enormous variability which characterizes field-plot experiments with sugarcane. The control of nutrient and moisture regimes alone is extremely helpful in lowering variability. All plant samples utilize the primary shoot rather than multiple shoots from a field propagated crown. Chemical administrations to the full canopy or individual leaf ranks can be performed with a thoroughness and precision not otherwise afforded in cane research. Under the present conditions of expanding roles for plant growth regulators and diminishing resources for supporting research, the young-adult model has a decisive role to play on behalf of the sugar industry.

\section{RESUMEN}

La eficacia de tres agentes químicos madurativos que han demostrado una actividad excepcional en pruebas con plantitas de caña de azúcar se evaluó de nuevo en plantas jóvenes adultas, de 14 semanas de edad y las cuales ya habían desarrollado el cogollo y 
cañas molturables. Polaris y CP $701: 39$ (ambos Monsanto Agricultural Products Co.) y PP 757 (ICI United States, Inc.) se le administraron a la misma variedad propagada idénticamente y cultivada en arena. También se reexaminaron dos materiales que anteriormente habian resultado inactivos: RH 1622 (Rohm and Haas Co.) y Ripenthol (Pennwalt Corp.). El periodo de tratamiento se extendió de 21 a 42 días. Polaris, CP 70139 y PP 757 sobresalieron otra vez en sus efectos sobre el crecimiento, el contenido en azúcar, los componentes proteicos y el comportamiento de los enzimas, mientras que $\mathrm{RH} 1622$ y Ripenthol dieron muy poca respuesta. Los tres compuestos mejoraron la calidad del jugo significativamente. Las respuestas en plantas adultas son muy similares a las obtenidas en plantitas. Los resultados se discuten en términos de una creciente validez en el uso de plantitas para la eliminación selectiva de agentes madurativos. Además, se discute la posibilidad de utilizar plantas jóvenes adultas, como un modelo para determinar la eficacia de futuros materiales de posible utilidad.

\section{LITERATURE CITED}

1. Alexander, A. G., and Montalvo-Zapata, R., Evaluation of chemical ripeners for sugarcane having constant nitrogen and water regimes. I. Growth, quality and enzymic responses of nine potential ripeners, Tropical Agr. 49: 35-44, 1973.

2. - . Sugarcane Physiology. A Comprehensive Study of the Saccharum Source-to-Sink System, Elsevier Scientific Publishing Co., Amsterdam, 1973.

3. -. Evaluation of candidate chemical ripeners with early-juvenile sugarcane, J. Agr. Univ. P.R. 60 (4): 443-50, 1976.

4. Anonymous, More sucrose with Polaris, commercial release by Monsanto Agricultural Products Co., January 1975. 